\title{
INSECTS INFESTING STORED GRAIN CROPS AND THEIR BIOLOGICAL CONTROL USING ENTOMOPATHOGENIC NEMATODES
}

\author{
B. M. Eldefrawy and A.M. Abd El-Raheem \\ Department of Economic Entomology \& Agricultural Zoology, Faculty of Agriculture, \\ Menoufia University
}

Received: Mar. 30, 2017

Accepted: Apr. 18, 2017

\begin{abstract}
The recent experiments were conducted to classify insects attacking stored grain crops with trail to control Tribolium confusum (Jacquelin du Val) and Bruchidius incarnates (Boheman, 1833) using entomopathogenic nematodes, Heterorhabditis bacteriophora Poinar, and Steinernema feltiae Filipjev. Results indicated that stored grains under study were attacked by 11 insect species. Wheat grains were infested with nine insects where the percentages of infestation varied from $0.2 \%$ to $40 \%$. Faba bean seeds were infested with two insects and the percentages of infestation varied from $1.5 \%$ to $50 \%$. Rice seeds were infested with only one insect with percentages of infestation varied from 3.6-26\%. Maize seeds were infested with eight insects and the percentages of infestation varied from $0.3 \%$ to $48 \%$. Regarding to the pathogenicity of entomopathogenic nematodes to tested insects, the results revealed that $100 \%$ mortality of T. confusum occurred with the treatments of $2000 \mathrm{lJs}$ of S. feltiae \& 1000, 2000 and $3000 \mathrm{lJs}$ of $\mathrm{H}$. bacteriophora. $100 \%$ mortality of $\mathrm{B}$. incarnates obtained with the treatments of 2000 and $3000 \mathrm{lJs}$ of S. feltiae \& $3000 \mathrm{lJs}$ of H. bacteriophora.
\end{abstract}

Key words: Stored grain insects, Survey, Biological control, Entomopathogenic nematodes.

\section{INTRODUCTION}

There are many insects attacking stored grains which in turn led to reduce both quality and quantity of infested grains (Warchalewski and Gralik, 2010). In developing countries, losses caused by pests attacking stored grains ranging between $10-50 \%$ of the total yield (Fornal et al., 2007, Upadhyay and Ahmed, 2011). Fumigation by chemical pesticides still the main method for control stored grain pests, these chemical pesticides have hazard effects on both the environment and the consumers, on the other hand caused insect resistance (Jovanovic et al., 2007; Lu and $\mathrm{Wu}, 2010$ ), therefore, scientists work to use other methods to control store insects rather than chemical pesticides.

In recent years, it has seen an increase attention for non-chemical methods of stored-product protection, including biological control of stored-product pests (Arbogast, 1984; Brower et al., 1996; Schoeller et al., 1997; Adler, 1998; Cox \&
Wilkin, 1998; Schoeller, 1998; Stengård, 2005; Shadia E. Abd El-Aziz, 2011; Traian et al., 2015 and Shaheen et al., 2016).

Entomopathogenic nematodes (EPNs) play as biological control agents for a wide range of insect species as they able to kill their hosts within 24-48 hours, furthermore, EPNs are harmless to plants and livestock and safe for the environment. EPNs characterised by their ability to search for their hosts and staying effective for a long time after application, moreover, it's easy to produce EPNs commercially at low costs (Canhilal, 2016). The use of entomopathogenic nematodes in the control of store product insects is a new field, however, entomopathogenic nematodes have not been previously tested against stored-product insects in natural environments. Recently, there are a few articles were published in this direction i.e. Trdan et al., (2006) who determined the efficacy of four entomopathogenic nematode species, S. feltiae, S. carpocapsae, $\mathrm{H}$. 
bacteriophora, and $H$. megidis at three different concentrations $(500,1000$, and 2000 IJs per adult) and three different temperatures $\left(15,20\right.$, and $\left.25^{\circ} \mathrm{C}\right)$ in control of the adults of stored grain pests, Sitophilus granarius and Oryzaephilus surinamensis under laboratory conditions. RamosRodriguez, et al., (2007) tested the efficacy of Steinernema riobrave against Tribolium castaneum, larvae, pupae and adult stages under laboratory coditions. Shahina and Salma (2009) evaluated the virulence of seven Pakistani strains of entomopathogenic nematodes included Steinernema pakistanense Shahina, Anis, Reid and Maqbool (Ham 10 strain); $S$. asiaticum Anis, Shahina, Reid and Rowe (211 strain); S. abbasi Elawad, Ahmad and Reid (507 strain); S. siamkayai Stock, Somsook and Reid (157 strain); S. feltiae Filipjev (A05 strains); Heterorhabditis bacteriophora Poinar (1743 strain); and $H$. indica Poinar, Karunakar and David (HAM64 strain) against last instar and adult stages of the pulse beetle, Callosobruchus chinensis, furthermore, Shahina and Salma (2010 and 2011) tested the same seven Pakistani strains of entomopathogenic nematodes against stored grain insect pest Sitophilus oryzae (L.) and Tribolium castaneum ,respectively.

Athanassiou, et al., (2010) examined the insecticidal effect of $H$. bacteriophora Poinar, S. carpocapsae (Weiser), and $S$. feltiae (Filipjev) against Mediterranean flour moth, Ephestia kuehniella (Zeller) larvae, lesser grain borer, Rhyzopertha dominica (F.) adults, rice weevil, S. oryzae (L.) adults, and confused flour beetle, $T$. confusum Jacquelin du Val larvae and adults stages under laboratory conditions in wheat grains. Laznik, and Trdan, (2010) tested the efficacy of three strains (B30, B49 and 3162) of $S$. feltiae to control adults of rice weevil $S$. oryzae. Shrestha and Kim (2010) reported that the two entomopathogenic bacteria, Photorhabdus temperata sub sp. temperata (Ptt) and Xenorhabdus nematophila (Xn), are symbiotically associated with the nematodes, $H$. megidis and $S$. carpocapsae, respectively, and found that a significant difference in pathogenicity was observed between these two bacteria against the red flour beetle, T. castaneum. Recently, in Egypt Sweelam et al., (2010) controlled red palm weevil, Rhynchophorus ferrugineus Oliver by entomopathogenic nematode species.

From these points of view, this research was conducted to identify insects attacking stored grain and seeds, as well as to throw a light on the possibility of using entomopathogenic nematodes, $H$. bacteriophora and $S$. feltiae in the biological control of the red flour beetle, $T$. castaneum and the faba bean beetle, Bruchidius incarnatus.

\section{MATERIALS AND METHODS}

Experiments were conducted at the laboratories of the Economic Entomology and Agricultural Zoology Department, Faculty of Agriculture, Menoufia University, Shebin Elkom, Egypt.

\section{1- Survey of insects infesting stored grains:}

Twenty five $\mathrm{kg}$ of each of the tested grains (Wheat, Triticum astivum, var. Sakha 93, Faba bean, Vicia faba, var. Giza 111, Rice, Oryzae spp, Maize, Zea mayes, var. Balady) were put in a cloth bag in the open greenhouse, left open to be naturally infested with insects for six months (June November, 2015).

Every month, randomized three samples each of one $\mathrm{kg}$ were taken from each crop seeds and examined for insect infestation. The obtained insects were identified and percentages of infested seeds were calculated.

\section{2- Pathogenicity of entomopath- ogenic nematodes to two grain insects.}




\subsection{Propagation of entomopath- ogenic nematodes:}

Two species of entomopathogenic nematodes: Heterorhabditis bacteriophora Poinar (Heterorhabditidae) and Steinernema feltiae Filipjev (Steinernematidae) were obtained from Dr. M.E. Sweelam biological laboratory, in the Econ. Ent. \& Agric. Zoology Dept. Fac. Agric. Menoufia Univ. The greater wax moth, Galleria mellonella were used for culturing both entomopathogenic nematodes using the method described by (White, 1927). White traps were used to harvest the infective Juveniles (IJs). Collected IJs were stored in plastic tubes $(50 \mathrm{ml})$ in a refrigerator adjusted to $10^{\circ} \mathrm{C}$ until used.

\subsection{Procedure of infection:}

Two of obtained insects, Tribolium confusum and Bruchidius incarnates were used in this study. Adults of both insects were subjected to infection at different concentrations of 50,100,500,1000, 2000 and 3000 of Heterorhabditis bacteriophora or Steinernema feltiae infective juveniles (IJs) $/ 10$ insects

Ten adult insects were kept in Petri dish, each $5-\mathrm{cm}$ diameter containing moist filter papers with the same diameter of Petri dishes, and exposed to entomopathogenic nematodes. Every nematode concentration was sprayed on the insects as $1 \mathrm{ml}$ distilled water containing nematodes, to keep filter paper wetted, drops of distilled water were added when needed. In control treatment, insects were sprayed with $1 \mathrm{ml}$ distilled water without nematodes. Each treatment was replicated three times. Mortality was checked after 24, 48, 72, $96 \mathrm{~h}$ for all concentrations of the two tested nematode species, and percentages of mortality were calculated for each nematode species at different concentrations using Abbott's formula (1925). Mortality percentage was corrected by Schneider-Orelli's formula (Püntener, 1981).

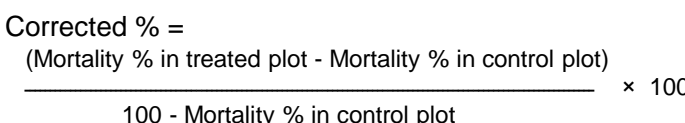

\section{RESULTS AND DISCUSSION 1-Survey of insects infesting} stored grains:

Data presented in table (1) indicated the presence of 11 insect species attacked the stored grain. These insects were Sitophilus granaries (L.), S. oryzae (L.), Sitotroga cerealella (Olivier), Tribolium confusum (Jacquelin du Val), T. castaneum (Herbst), Bruchidius incarnates (Boheman, 1833), Bruchus rufimanus (Boheman, 1833), Tenebriodes mauritanicus L., Rhizopertha dominica L., Plodia interpunctella (Hubner) and Ephestia kuehniella Zell.

Results indicated that the wheat grains were infested with nine insects; Granary weevil, S. granaries, Angoumois grain moth, S. cerealella, Rice weevil, S. oryzae, Confused flour beetle, T. confusum, Red flour beetle, T. castaneum, Cadelle beetle $T$. mauritanicus, Lesser grain borer, $R$. dominica, Indian meal moth, $P$. interpunctella, and Mediterranean flour moth, E. kuehniella.

The percentages of infestation varied from $0.2 \%$ to $40 \%$, where the highest percentages in wheat grains was $40 \%$ under six months of natural infestation with $T$. confusum \& $T$. castaneum, followed by S. oryzae and S. cerealella recording $35 \%$, while the lowest infestation was $6 \%$ and $2 \%$ with P. interpunctella, and E. kuehniella, respectively.

Results also indicated that the faba bean seeds were infested with the two insects; Faba bean beetle, $B$. incarnatus, and Large broad bean beetle, $B$. rufimanus, where the percentages of infestation varied from $1.5 \%$ to $50 \%$, the highest infested seeds percentages were $50 \%$ under six months of natural infestation with $B$. incarnatus, followed by $B$. rufimanus recording $31 \%$. 
Table (1): Monthly infestation of different seeds with insects along six months of storage (June - November, 2015)

\begin{tabular}{|c|c|c|c|c|c|c|c|}
\hline \multirow[t]{2}{*}{ Insect species } & \multirow{2}{*}{$\begin{array}{l}\text { Seed } \\
\text { crops }\end{array}$} & $\begin{array}{l}\text { June, } \\
2015\end{array}$ & $\begin{array}{l}\text { July, } \\
2015\end{array}$ & $\begin{array}{l}\text { Aug., } \\
2015\end{array}$ & $\begin{array}{l}\text { Sept., } \\
2015\end{array}$ & $\begin{array}{l}\text { Oct., } \\
2015\end{array}$ & $\begin{array}{l}\text { Nov., } \\
2015\end{array}$ \\
\hline & & \multicolumn{6}{|c|}{$\%$ infested seeds } \\
\hline \multirow{4}{*}{$\begin{array}{l}\text { Granary weevil } \\
\text { Sitophilus granaries }\end{array}$} & Wheat & 0.0 & 0.0 & 1.0 & 6.0 & 31.0 & 33.0 \\
\hline & Faba bean & 0.0 & 0.0 & 0.0 & 0.0 & 0.0 & 0.0 \\
\hline & Rice & 0.0 & 0.0 & 0.0 & 0.0 & 0.0 & 0.0 \\
\hline & Maize & 0.0 & 0.0 & 1.0 & 6.0 & 15.0 & 28.0 \\
\hline \multirow{4}{*}{$\begin{array}{l}\text { Angoumois grain moth } \\
\text { Sitotroga cerealella }\end{array}$} & Wheat & 0.0 & 0.3 & 1.5 & 6.0 & 20.0 & 35.0 \\
\hline & Faba bean & 0.0 & 0.0 & 0.0 & 0.0 & 0.0 & 0.0 \\
\hline & Rice & 0.0 & 0.0 & 0.0 & 0.0 & 0.0 & 0.0 \\
\hline & Maize & 0.0 & 0.3 & 1.5 & 6.0 & 20.0 & 35.0 \\
\hline \multirow{4}{*}{$\begin{array}{l}\text { Rice weevil } \\
\text { Sitophilus oryzae }\end{array}$} & Wheat & 0.0 & 0.3 & 1.5 & 6.0 & 20.0 & 35.0 \\
\hline & Faba bean & 0.0 & 0.0 & 0.0 & 0.0 & 0.0 & 0.0 \\
\hline & Rice & 0.0 & 0.0 & 0.0 & 0.0 & 0.0 & 0.0 \\
\hline & Maize & 0.0 & 0.3 & 1.5 & 6.0 & 0.0 & 28.0 \\
\hline \multirow{4}{*}{$\begin{array}{l}\text { Confused flour beetle } \\
\text { Tribolium confusum } \\
\text { Red flour beetle } \\
\text { Tribolium castaneum }\end{array}$} & Wheat & 0.0 & 0.0 & 0.0 & 10.0 & 25.0 & 40.0 \\
\hline & Faba bean & 0.0 & 0.0 & 0.0 & 0.0 & 0.0 & 0.0 \\
\hline & Rice & 0.0 & 0.0 & 0.0 & 0.0 & 0.0 & 0.0 \\
\hline & Maize & 0.0 & 0.0 & 0.0 & 10.0 & 25.0 & 40.0 \\
\hline \multirow{4}{*}{$\begin{array}{l}\text { Faba bean beetle } \\
\text { Bruchidius incarnatus }\end{array}$} & Wheat & 0.0 & 0.0 & 0.0 & 0.0 & 0.0 & 0.0 \\
\hline & Faba bean & 1.5 & 3.6 & 6.0 & 20.0 & 32.0 & 50.0 \\
\hline & Rice & 0.0 & 0.0 & 0.0 & 0.0 & 0.0 & 0.0 \\
\hline & Maize & 0.0 & 0.0 & 0.0 & 0.0 & 0.0 & 0.0 \\
\hline \multirow{4}{*}{$\begin{array}{l}\text { large broad bean beetle } \\
\text { Bruchus rufimanus }\end{array}$} & Wheat & 0.0 & 0.0 & 0.0 & 0.0 & 0.0 & 0.0 \\
\hline & Faba bean & 0.0 & 0.0 & 0.0 & 0.0 & 27.0 & 31.0 \\
\hline & Rice & 0.0 & 0.0 & 0.0 & 0.0 & 0.0 & 0.0 \\
\hline & Maize & 0.0 & 0.0 & 0.0 & 0.0 & 0.0 & 0.0 \\
\hline \multirow{4}{*}{$\begin{array}{l}\text { Cadelle beetle } \\
\text { Tenebriodes mauritanicus }\end{array}$} & Wheat & 0.0 & 0.0 & 1.5 & 3.0 & 10.0 & 23.0 \\
\hline & Faba bean & 0.0 & 0.0 & 0.0 & 0.0 & 0.0 & 0.0 \\
\hline & Rice & 0.0 & 0.0 & 0.0 & 0.0 & 0.0 & 0.0 \\
\hline & Maize & 0.0 & 0.0 & 1.5 & 4.0 & 12.0 & 26.0 \\
\hline \multirow{4}{*}{$\begin{array}{l}\text { Lesser grain borer } \\
\text { Rhizopertha dominica }\end{array}$} & Wheat & 0.0 & 2.5 & 2.6 & 5.0 & 22.0 & 31.0 \\
\hline & Faba bean & 0.0 & 0.0 & 0.0 & 0.0 & 0.0 & 0.0 \\
\hline & Rice & 0.0 & 0.0 & 3.6 & 4.0 & 12.0 & 26.0 \\
\hline & Maize & 0.0 & 3.5 & 5.6 & 8.0 & 34.0 & 48.0 \\
\hline \multirow{4}{*}{$\begin{array}{l}\text { Indian meal moth } \\
\text { Plodia interpunctella }\end{array}$} & Wheat & 0.0 & 0.0 & 0.0 & 0.3 & 1.5 & 6.0 \\
\hline & Faba bean & 0.0 & 0.0 & 0.0 & 0.0 & 0.0 & 0.0 \\
\hline & Rice & 0.0 & 0.0 & 0.0 & 0.0 & 0.0 & 0.0 \\
\hline & Maize & 0.0 & 0.0 & 0.0 & 0.3 & 1.5 & 6.0 \\
\hline \multirow{4}{*}{$\begin{array}{l}\text { Mediterranean flour moth } \\
\text { Ephestia kuehniella }\end{array}$} & Wheat & 0.0 & 0.0 & 0.0 & 0.3 & 2.0 & 2.0 \\
\hline & Faba bean & 0.0 & 0.0 & 0.0 & 0.0 & 0.0 & 0.0 \\
\hline & Rice & 0.0 & 0.0 & 0.0 & 0.0 & 0.0 & 0.0 \\
\hline & Maize & 0.0 & 0.0 & 0.0 & 0.3 & 1.5 & 6.0 \\
\hline
\end{tabular}


As for rice seeds, it was infested with only Lesser grain borer, $R$. dominica L., with $\%$ infestation of $3.6-26 \%$.

Regarding to maize seeds, it was infested with the eight insects; Granary weevil, S. granarius, Angoumois grain moth, S. cerealella, Rice weevil, S. oryzae, Confused flour beetle, T. Confusum, Red flour beetle, T. castaneum, Cadelle beetle, $T$. mauritanicus, Lesser grain borer, $R$. dominica, Indian meal moth, $P$. interpunctella and Mediterranean flour moth, E. kuehniella. The infestation varied from $0.3 \%$ to $48 \%$, the highest damaged seed percentages of maize stored under six months of natural infestation was $48 \%$ with $R$. dominica, followed by $T$. Confusum, $T$. castaneum $40 \%$, S. cerealella $35 \%$, while it was $28 \%$ with both $S$. granaries and $S$. oryzae, moreover, the infestation with $T$. mauritanicus recorded $26 \%$. The lowest damage infestation was only $6 \%$ with both of P. interpunctella, and E. kuehniella.

\section{2- Pathogenicity of EPN to tested insects:}

Results in table (2) show the effect of different doses of entomopathogenic nematode, Steinernema feltiae on the mortality percentages of confused flour beetle, $T$. confusum adults, under laboratory conditions. The highest averages of corrected mortality of $T$. confusum adults were recorded with the treatment of $2000 \mathrm{IJS}$ of entomopathogenic nematode, S. feltiae giving $100 \%$, followed by the treatment of $500 \mathrm{IJs}$ of $S$. feltiae nematode as it recorded $81.58 \%$. The treatment of $100 \mathrm{lJs}$ of $S$. feltiae nematode gave $76.32 \%$, while the treatment of $1000 \mathrm{IJs}$ of $S$. feltiae gave the least averages of the corrected mortality of the adult stage insects which calculated as $68.42 \%$.

Results in table (3) show the effect of different doses of entomopathogenic nematode, Heterorhabditis bacteriophora on the mortality percentages of confused flour beetle, $T$. confusum adults under laboratory conditions. Results indicated that the highest averages of corrected mortality of confused flour beetle, $T$. confusum adults were registered with the treatments of 1000 , 2000,3000 IJs of entomopathogenic nematode, $H$. bacteriophora giving $100 \%$, followed by the treatment of 500 IJs of $H$. bacteriophora nematode as it recorded $88.57 \%$, and the treatment of $100 \mathrm{lJs}$ which recorded $82.86 \%$.

Table (2): Mortality percentages of confused flour beetle, $T$. confusum adults as affected by $S$. feltiae nematode under laboratory conditions ( $\left.25 \pm 3{ }^{\circ} \mathrm{C} \& 65 \% \mathrm{RH}\right)$

\begin{tabular}{|c|c|c|c|c|c|c|}
\hline \multirow{2}{*}{$\begin{array}{c}\text { Concentration } \\
\text { of nematode juveniles }\end{array}$} & \multicolumn{5}{|c|}{ Mortality percentages } & \multirow{2}{*}{$\begin{array}{c}\text { Corrected } \\
\text { mortality }\end{array}$} \\
\cline { 2 - 7 } & $\mathbf{2 4} \mathbf{~ h}$ & $\mathbf{4 8} \mathbf{~}$ & $\mathbf{7 2} \mathbf{~ h}$ & $\mathbf{9 6 ~ h}$ & Mean & \\
\hline $\mathbf{1 0 0}$ & 80 & 80 & 60 & 90 & 77.5 & 76.32 \\
\hline $\mathbf{5 0 0}$ & 80 & 80 & 80 & 90 & 82.5 & 81.58 \\
\hline $\mathbf{1 0 0 0}$ & 60 & 60 & 80 & 80 & 70 & 68.42 \\
\hline $\mathbf{2 0 0 0}$ & 100 & 100 & 100 & 100 & 100 & 100.00 \\
\hline $\mathbf{3 0 0 0}$ & 70 & 70 & 80 & 80 & 75 & 73.68 \\
\hline Control & 0 & 0 & 10 & 10 & 5 & - \\
\hline
\end{tabular}


Table (3): Mortality percentages of confused flour beetle, $T$. confusum adults as affected by $H$. bacteriophora nematode under laboratory conditions $\left(25 \pm 3{ }^{\circ} \mathrm{C} \& 65 \%\right.$ $\mathrm{RH})$

\begin{tabular}{|c|c|c|c|c|c|c|}
\hline \multirow{2}{*}{$\begin{array}{c}\text { Concentration } \\
\text { of nematode juveniles }\end{array}$} & \multicolumn{5}{|c|}{ Mortality percentages } & Corrected \\
\cline { 2 - 6 } & $\mathbf{2 4} \mathbf{~}$ & $\mathbf{4 8} \mathbf{~}$ & $\mathbf{7 2} \mathbf{~}$ & $\mathbf{9 6} \mathbf{~}$ & Mean & 82.86 \\
\hline $\mathbf{1 0 0}$ & 80 & 80 & 90 & 90 & 85 & 88.57 \\
\hline $\mathbf{5 0 0}$ & 80 & 90 & 90 & 100 & 90 & 100 \\
\hline $\mathbf{1 0 0 0}$ & 100 & 100 & 100 & 100 & 100 & 100 \\
\hline $\mathbf{2 0 0 0}$ & 100 & 100 & 100 & 100 & 100 & 100 \\
\hline $\mathbf{3 0 0 0}$ & 100 & 100 & 100 & 100 & 100 & - \\
\hline Control & 10 & 10 & 10 & 20 & 12.5 & - \\
\hline
\end{tabular}

As for the toxic effect of the entomopathogenic nematode, $S$. feltiae on faba bean beetle, $B$. incarnates adults, results in table (4) indicated that the highest averages of corrected mortality of $B$. incarnatus adults were registered with the treatments of 2000 and 3000 IJs of entomopathogenic nematode, $S$. feltiae giving $100 \%$, followed by the treatments of $500,1000 \mathrm{IJs}$ of $S$. feltiae nematode as it recorded 62.16 and $51.35 \%$, respectively, while the least averages of the corrected mortality of $B$. incarnates adults were recorded with the treatment of $100 \mathrm{IJs}$ which was $35.14 \%$.

Results in table (5) show the effect of different doses of entomopathogenic nematode, Heterorhabditis bacteriophora against the faba bean beetle, Bruchidius incarnates adults under laboratory conditions. Results indicated that the highest averages of corrected mortality of $B$. incarnatus adults were registered with the treatment of $3000 \mathrm{IJS}$ of entomopathogenic nematode, $H$. bacteriophora giving $100 \%$, followed by the treatment of $2000 \mathrm{IJs}$ of $\mathrm{H}$. bacteriophora nematode giving $94.87 \%$, then the treatment of $500 \mathrm{IJs}$ of $\mathrm{H}$. bacteriophora, which gave $87.18 \%$. The averages of the corrected mortality of $B$. incarnatus adults with the treatments of 100 and 1000 IJs of entomopathogenic nematode, $H$. bacteriophora were calculated as 84.62 and $79.49 \%$, respectively as overall averages.

The obtained results are in harmony with those obtained by Trdan et al., (2006) who proved that the entomopathogenic nematodes were efficient in the control of $S$. granarius and Oryzaephilus surinamensis at $20^{\circ} \mathrm{C}$.

Ramos-Rodriguez, et al., (2007) who reported that in laboratory bioassays, $S$. riobrave reduced survival of red flour beetle, T. castaneum, stages to $27.4 \%$ in treatments compared to $77.9 \%$ in the control which mean $S$. riobrave compete as a biological control agent for stored-product insects.

Shahina and Salma (2009, 2010 and 2011) found that $H$. bacteriophora, $S$. siamkayai, and $S$. pakistanense showed high virulence to $C$. chinensis, $S$. oryzae and $T$. Castaneum stages, respectively, as the mortality of adult, larval and pupal stages were higher in the nematode treatments than in the control in laboratory bioassays.

Athanassiou, et al., (2010) who used entomopathogenic nematodes, $H$. bacteriophora, S. feltiae and S. carpocapsae at different concentrations $(10,50,100,150$, 500,1000 , and $2000 \mathrm{lJs} /$ insect) in the control of the rice weevil, $S$. oryzae, the red flour beetle, $T$. castaneum, the lesser grain borer, $R$. dominica (F.), the Mediterranean flour moth, E. kuehniella (Zeller), and the 
pulse beetle, $C$. chinensis (L.) under laboratory conditions.

Table (4): Mortality percentages of faba bean beetle, B. incarnates adults as affected by S. feltiae nematode under laboratory conditions ( $25 \pm 3$ ㅇ $\mathrm{C} \& 65 \% \mathrm{RH})$

\begin{tabular}{|c|c|c|c|c|c|c|}
\hline \multirow{2}{*}{$\begin{array}{c}\text { Concentration } \\
\text { of nematode juveniles }\end{array}$} & \multicolumn{5}{|c|}{ Mortality percentages } & \multirow{2}{*}{$\begin{array}{l}\text { Corrected } \\
\text { mortality }\end{array}$} \\
\hline & $24 \mathrm{~h}$ & $48 \mathrm{~h}$ & $72 \mathrm{~h}$ & $96 \mathrm{~h}$ & Mean & \\
\hline 100 & 20 & 20 & 60 & 60 & 40 & 35.14 \\
\hline 500 & 20 & 80 & 80 & 80 & 65 & 62.16 \\
\hline 1000 & 20 & 40 & 60 & 100 & 55 & 51.35 \\
\hline 2000 & 100 & 100 & 100 & 100 & 100 & 100 \\
\hline 3000 & 100 & 100 & 100 & 100 & 100 & 100 \\
\hline Control & 0 & 10 & 10 & 10 & 7.5 & - \\
\hline
\end{tabular}

Table (5): Mortality percentages of faba bean beetle, $B$. incarnates adults as affected by $H$. bacteriophora nematode under laboratory conditions ( $25 \pm 3 \stackrel{\circ}{\circ} \& 65 \% \mathrm{RH}$ )

\begin{tabular}{|c|c|c|c|c|c|c|}
\hline \multirow{2}{*}{$\begin{array}{c}\text { Concentration } \\
\text { of nematode juveniles }\end{array}$} & \multicolumn{5}{|c|}{ Mortality percentages } & \multirow{2}{*}{$\begin{array}{l}\text { Corrected } \\
\text { mortality }\end{array}$} \\
\hline & $24 \mathrm{~h}$ & $48 \mathrm{~h}$ & $72 \mathrm{~h}$ & $96 \mathrm{~h}$ & Mean & \\
\hline 100 & 60 & 80 & 100 & 100 & 85 & 84.62 \\
\hline 500 & 50 & 100 & 100 & 100 & 87.5 & 87.18 \\
\hline 1000 & 60 & 60 & 100 & 100 & 80 & 79.49 \\
\hline 2000 & 80 & 100 & 100 & 100 & 95 & 94.87 \\
\hline 3000 & 100 & 100 & 100 & 100 & 100 & 100 \\
\hline Control & 0 & 0 & 0 & 10 & 2.5 & - \\
\hline
\end{tabular}

\section{Conclusion}

It could be concluded that the use of entomopathogenic nematodes (EPNs), Heterorhabditis bacteriophora and Steinernema feltiae in the control of stored insect products i.e. confused flour beetle, Tribolium confusum, and the faba bean beetle, Bruchidius incarnatus registered good results in laboratory bioassays, but it needs more studies where solutions should be sought to facilitate the application of entomopathogenic nematodes in natural conditions within grain stores, the combination of EPNs with some other biotechnical methods may be one of the solutions in the future.

\section{Acknowledgement}

The authors acknowledge Dr. Mohamed E. Sweelam Professor of Parasitology and Nematology for providing with the entomopathogenic nematodes, kind help during work and reviewing the manuscript.

\section{REFERENCES}

Abbott, W. S. (1925). A method of computing the effectiveness of an insecticide. J. Econ. Ent., 18, 265-267.

Adler, C. (1998). What is integrated storage protection? In: C. Adler \& M. Schoeller 
(eds). Integrated Protection of Stored Products. IOBC WPRS Bulletin 21, 1-8.

Arbogast, R. T. (1984). Biological control of stored-product insects: status and prospects. In: F. J. Baur (ed.), Insect Management for Food Storage and Processing. Americ. Assoc. Cereal Chem., St. Paul, Minnesota, 225-238.

Athanassiou, C. G., N. G. Kavallieratos, H. Menti and E. Karanastasi (2010). Mortality of four stored product pests in stored wheat when exposed to doses of three entomopathogenic nematodes. J. Econ. Ent., 103 (3): 977-984.

Brower, J. H., L. Smith, P. V. Vail and P. W. Flinn (1996). Biological control. In: B. Subramanyam \& D.W. Hagstrum (eds), Integrated Management of Insects in Stored Products. Marcel Dekker, Inc., New York, 223-286.

Canhilal (2016). The use of entomopathogens in the controlling of insect Pests of stored product. Series A. Agronomy, 235- 240.

Cox, P. D. and D. R. Wilkin (1998). A review of the options for biological control against invertebrate pests of stored grain in the UK. In: C. Adler \& M. Schoeller (Eds), Integrated Protection of Stored Products. IOBC WPRS Bulletin 21, 2732. search 54, 689-713.

Fornal, J., T. Jeliński, J. Sadowska, S. Grundas, J. Nawrot, A. Niewiara, J.R. Warchalewski and W. Błaszczak (2007). Detection of granary weevil Sitophilus granarius L. eggs and internal stage in wheat grain using soft X-ray and image analysis. J. of Stored Product Res. 43, 142-148.

Jovanovic, Z., M. Kostic and Z. Popovic (2007). Grain-protective properties of herbal extracts against the bean weevil Acanthoscelides obtectus Say. Indust. Crop and Produc. 26, 100-104.

Laznik, Z. S. Trdan (2010). Intraspecific variability of Steinernema feltiae (Filipjev) (Rhabditida: Steinernematidae) as biological control agent of rice weevil Sitophilus oryzae [L.] (Coleoptera,
Curculionidae) adults. Acta Agric. Slovenica, 95 (1): 51-59.

Lu, J. and S.H. Wu (2010). Bioactivity of essential oil from Ailanthus altissima bark against 4 major stored-grain insects. African J. Microb. Res. 4,154-157.

Püntener W. (1981). Manual for field trials in plant protection second edition. Agricultural Division, Ciba-Geigy Limited.

Ramos-Rodriguez, O., J. F. Campbell and S. B. Ramaswamy (2007). Efficacy of the entomopathogenic nematode Steinernema riobrave against the storedproduct insect pests Tribolium castaneum and Plodia interpunctella. Biol. Cont., 40 (1): 15-21.

Schoeller, M. (1998). Integration of biological and non-biological methods to control arthropods infesting stored products. In: C. Adler \& M. Schoeller (eds.), Integrated Protection of Stored Products. IOBC WPRS Bulletin 21: 1325.

Schoeller, M., S. Prozell, A.G. Al-Kirshi and C.H. Reichmuth (1997).Towards biological control as a major component of integrated pest management in stored product protection. J. Stored Product Res., 33: 81-97.

Shadia E. Abd El-Aziz (2011). Control Strategies of Stored Product Pests. Journal of Entomology, 8: 101122.

Shaheen, F. A., M. W. Akram, M. A. Rashid, M. Nadeem, M. Saeed, M. Husain and K. Mehmood (2016). Biological control of pulse beetle Callosobruchus chinensis L. (Bruchidae: Coleoptera) in stored chickpea grains using entomopathogenic fungus Beauveria bassiana Balsamo. J. Ent. and Zool. Studies, 4(4): 1076-1083.

Shahina F. and J. Salma (2009). Laboratory evaluation of seven Pakistani strains of entomopathogenic nematodes against a stored grain insect pest, pulse beetle Callosobruchus chinensis (L.). J. Nematol., 41 (4): 255-260.

Shahina, F. and J. Salma (2010). Laboratory evaluation of seven Pakistani strains of 
entomopathogenic nematode against stored grain insect pest Sitophilus oryzae L. Pakistan J. Nematol., 28 (2): 295-305.

Shahina F. and J. Salma (2011). Pakistani Strains of Entomopathogenic Nematode as A Biological Control Agent Against Stored Grain Pest, Tribolium Castaneum. Pak. J. Nematol., 29 (1): 25-34.

Shrestha, S. and Y.G. Kim (2010) Differential pathogenicity of two entomopathogenic bacteria, Photorhabdus temperate subsp. Temperate and Xenorhabdus nematophila against the red flour beetle, Tribolium castaneum. J.Asia-Pacific Ent., 13(3): 209-213.

Stengård H. L. (2005) Biological Control of Stored-Product Pests. In: Pimentel, D (ed.), Encyclopedia of Pest Management. Marcel Dekker, New York.

Sweelam, M. E., A. S. Albarrak, A. A. Abd El-All and A. M. Kella (2010). Biological control of the red palm weevil, Rhynchophorus ferrugineus Oliver (Coleoptera: Curculionidae) by entomopathogenic nematode species. Annals of Agric. Sci., Moshtohor, 48(2): $21-28$.
Traian, M., L. Carmen, F. Viorel, C. Andrei and C. Florentin (2015). Experimental Model for Biological Control of Stored Grain Pests. J. Agric. Sci. and Techno., 5: 793-798.

Trdan, S., M. Vidrih and N. Valic (2006). Activity of four entomopathogenic nematode species against young adults of Sitophilus granaries (Coleoptera: Curculionidae) and Oryzaephilus surinamensis (Coleoptera: Silvanidae) under laboratory conditions. J. Plant Diseases and Protec., 113 (4): 168-173.

Upadhyay, R.K. and S. Ahmad (2011). Management strategies for control of stored grain insect pests in farmer stores and public warehouses. World J. Agric. Sci., 7(5): 527-549.

Warchalewski, J.R. and J. Gralik (2010). Influence of microwave heating on biological activities and electrophoretic pattern of albumin fraction of wheat grain. Cereal Chemist., 87 (1): 35-41.

White, G.F. (1927). A method for obtaining infective nematode larvae from cultures. Sci. 66 (1709): 302-303. 


\title{
الحشرات التى تصيب حبوب المحاصيل المخزونة ومكافحتها الحيوية باستخدام النيماتودا الممرضة للحشرات
}

\author{
باسم محمد الافراوى ، أحمد محمد عبد الرحيم \\ قسم الحشرات الاقتصادية والحيوان الزراعى - كلية الزراعة - جامعة المنوفية
}

أجريت هذه الدراسة بمعمل البيولوجى - بكلية الزراعة . جامعة المنوفية لحصر أهم الحشرات النى تصيب الحبوب المخزونة تحت الظروف الطبيعية ودراسة إمكانية مكافحة حشرتى خنفساء الدقيق المتشابهة وخنفساء الفول

الصغيرة باستخدام نوعين من النيماتودا الممرضة للحشرات Heterorhabditis bacteriophora و Steinernema feltiae أظهرت النتائج أن الحبوب المخزونة تحت الدراسة (القمح- الفول البلدي- الأرز - الذرة) قد أصيبت بـ 11 نوع حشرى هم سوسة الحبوب وسوسة الأرز وفراشة الحبوب وخنفساء الكادل وخنفساء الدقبق المنتابهه والصدئية

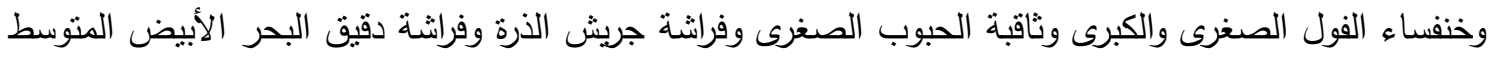

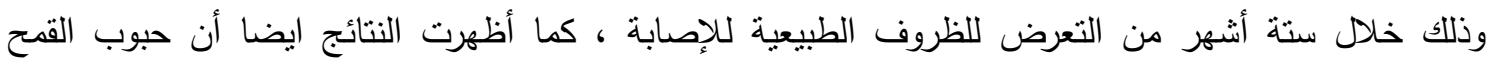

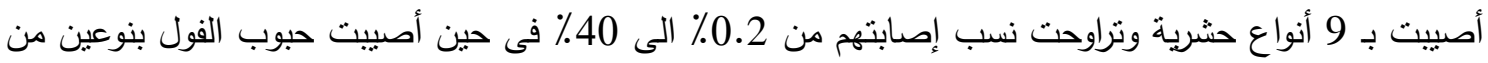

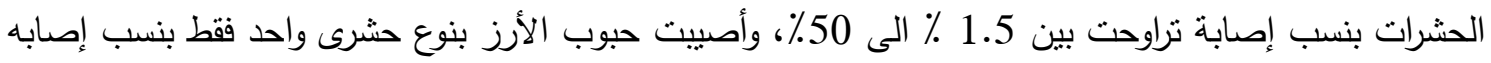
تراوحت بين 3.6٪ الى 26٪ ، أما حبوب الذرة فقد أصييت بـ 8 أنواع حشرية وتراوحت نسب إصابتهح من 0.3

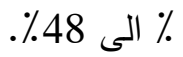

بالنسبة للاراسة المعملية لتقدير كفاءة نوعين من النيماتودا الممرضة للحشرات فى مكافحة الأطوار الكاملة لكل من حشرتى خنفساء الدقيق المتشابهة وخنفساء الفول الصغيرة وذلك بتعريض الأطوار الكاملة لهذه الحشرات لأعداد

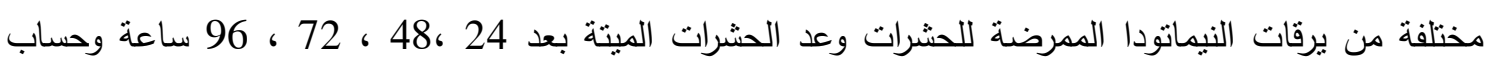
نسب الموت المصححة ، قد أثنتت النتائج نجاح كل من نوعى النيماتودا تحت الإختبار فى مكافحة أطوار الحشرات الكاملة تحت الدراسة وتراوحت نسب الموت من 35.14٪ حتى 100 ٪ وقد اوضحت النتائج ان نسبة كن

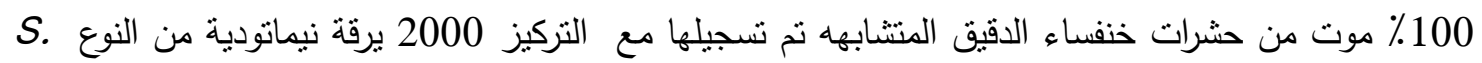

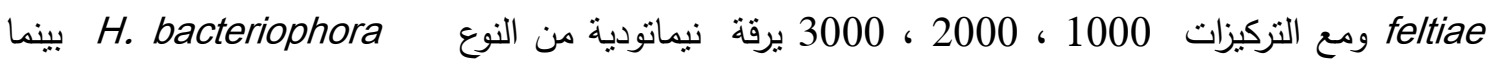

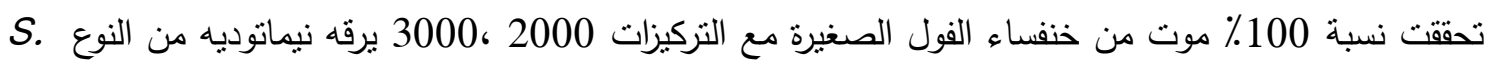

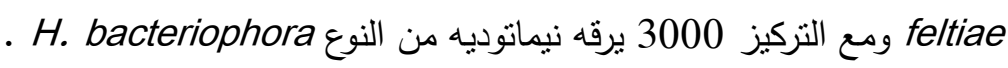

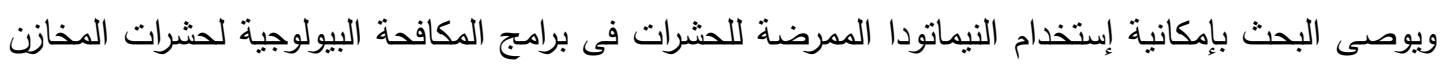
تحت الظروف المعملية ، لكننا بحاجه إلى مزيد من الدراسات لإيجاد حلول لتسهيل نطبيق النيماتودا الممرضة للحشرات في الظروف الطبيعية داخل مخازن الحبوب. 